\title{
Ibn Abī Ishạāq (d. ca. 125/743) and His Scholarly Network
}

\author{
Monique Bernards
}

\section{1 \\ Introduction}

The field of Arabic linguistics started in the second half of the first Islamic century with the study of the Arabic language ('Arabiyya) in close connection with qur’ānic studies, and gradually developed into a technical, scientific endeavour of its own, covering Arabic grammar ( $n a h w$ ), lexicography (lugha), as well as elaborate studies of poetry. ${ }^{1}$

Three main hypotheses regarding the early development of Arabic grammar as a distinct specialisation have been espoused over the years. The traditional account tags the beginning of the study of Arabic grammar to Abu al-Aswad al-Du'alī (d. ca. 69/688-689), a Basran judge (qadi) who "invented" the discipline at the instigation of the fourth caliph 'Alī b. Abī Tâlib (r. 35-4o/656661): the influx of non-Arab Muslims, speaking Arabic, caused corruption of the language of the Qurān. Moreover, those who knew the text, the Prophet's Companions, were passing away. Not only did the qur'ānic text require preservation, the do's and don'ts of the Arabic language needed to be set down. ${ }^{2}$ Abū al-Aswad al-Du'alī reportedly had written a few chapters on Arabic grammar. ${ }^{3}$ A second theory is that Arabic grammar was an innate Islamic specialisation that co-jointly evolved with Islamic law. Finally, a third thesis suggests

1 At a later stage, $n a h w$ would additionally come to include the connotation of syntax set apart from tașrīf, morphology (see Joyce Åkesson, "Șarf," in Encyclopaedia of Arabic Language and Linguistics, ed. Kees Versteegh, 5 vols. (Leiden: Brill, 2006-2009), 4:118-122). The period I cover in this article precedes this shift in meaning.

2 See Monique Bernards, "Abū l-Aswad al-Du’alī," in Encyclopaedia of Islam, THREE, Yearbook 2012 (Leiden: Brill, 2019), 62-64.

3 Abū Saīd al-Ḥasan b. 'Abd Allāh al-Sīrāfī, Akhbār al-nahwwiyȳ̄n al-Bașriyȳ̄n, ed. Fritz Krenkow (Paris: Paul Geuthner and Beirut: Imprimerie Catholique, 1936), 18; 'Abd al-Wahīd b. 'Alī Abū al-Ṭayyib, Marātib al-naḥwiyyīn, ed. Muḥammad Abū al-Faḍl Ibrāhīm (Cairo: Maktabat Nahụa, 1955), 6; Jamāl al-Dīn Abū al-Ḥasan 'Alī b. Yūsuf al-Qifțī, Inbāh al-ruwāt 'alā anbāh alnuḥāt, ed. Muhammad Abū al-Faḍl Ibrāhīm, 4 vols. (Cairo: Dār al-Fikr and Beirut: Mu’assasat al-Kutub, 1986), 51 . 
that the Greek philosophical tradition, through the translation of philosophical works and/or owing to direct contact between the Arabs and Hellenistic culture, contributed to the emergence of grammar as a field of systematic inquiry. ${ }^{4}$

Sïbawayhi's (d. ca. 180/796) al-Kitāb (The Book) is considered the crowning achievement in the field of Arabic grammar. But how Sibawayhi got there is still unknown due to the lack of extant grammatical works dating from before his time. This leaves us with a gap in the development of this specialisation. One way to fill this gap is to use a method that does not need such extant works, like Social Network Analysis. In what follows, an analysis of the social and intellectual contacts of one particular scholar-the Basran scholar Ibn Abī Ishāa — who lived decades before Sïbawayhi, sheds light on the otherwise dark early period of Arabic grammar.

I first discuss the rationale for examining Ibn Abī Ishạa and his intellectual circle, which is followed by a short biography of the scholar. I then describe how information was collected and formatted for Social Network Analysis, concentrating on one approach to network analysis, the "sociogram," after which we go directly to the sociogram I put together, that of Ibn Abī Ishāā's networkthe main subject of this article. After summarising the results, I will discuss what they tell us about the development of Arabic linguistics in general and Arabic grammar (nahw) in particular. As we will see, we will be able to fill in some details about the "dark age" from which no grammatical works survive by studying the contacts of Ibn Abī Isḥāq.

Ibn Abī Isḥāq (d. ca. 125/743) belongs to a group of early scholars identified by "awä'il" as pioneers in the field of Arabic language studies. Awäil are narratives beginning with the expression awwalu man, "the first person who ...," or awwalu $m \bar{a}$, "the first time something ...," and tell in retrospect about novelties, about someone doing something for the first time (awwalu man) or something

4 Michael Carter is an advocate of the grammar/law thesis. The possibility of Greek influence on Arabic grammar was first suggested by A. Merx (Historia artis grammaticae apud syros) at the end of the nineteenth century and further elaborated on by Kees Versteegh who offers an overview of the diverse viewpoints on this subject. See Michael G. Carter, "Les origines de la grammaire Arabe," Revue des études islamiques 40 (1972): 69-97; Kees Versteegh, Greek Elements in Arabic Linguistic Thinking (Leiden: Brill, 1977); Kees Versteegh, Arabic Grammar and Qur'ānic Exegesis in Early Islam (Leiden: Brill, 1993), 20-36. 
having been done for the first time (awwalu $m \bar{a})$. Awāil narratives cover a wide range of subjects-from theological and legal themes, to historical, political and cultural topics. Awāil about historical events of the Islamic era from the Prophet's time onwards typically refer back to authoritative individuals who did something for the first time that had a long lasting effect, introducing some new tool or being the originator of a science, for instance. ${ }^{5}$ An investigation of aw $\bar{a}$ il reports traditionally ascribed to Arabic language scholars from the first four centuries of Islam suggests that Ibn Abī Ishāq was the first "real grammarian" in the Arabic tradition. ${ }^{6}$ At any rate, it is evident that Ibn Abī Isḥāq played an important role at the very outset of grammatical activities and as such serves as the focus of our investigation here.

Ibn Abī Isḥāq was a mawlā from Ḥạ̣ramawt and a specialist in hadith and qur'ānic reading ( ir $\left.^{\prime} \bar{a}^{3} a\right)$, but his heart was apparently in Arabic language studies. ${ }^{7} \mathrm{He}$ is amongst the earliest individuals active in the field of grammar men-

5 See Monique Bernards, "Awāill," in Encyclopaedia of Islam THREE, Yearbook 2014 (Leiden: Brill, 2019), 120-127.

6 For a study of how the early Arabic grammatical tradition marked the highlights of its own development through awāil stories, see Monique Bernards, "Pioneers of Arabic Linguistic Studies," in In the shadow of Arabic: The Centrality of Language to Arabic Culture. Studies Presented to Ramzi Baalbaki on the Occasion of his Sixtieth Birthday, ed. Bilal Orfali (Leiden: Brill, 2011), 197-220. Rafael Talmon, "Naḩwiyyūn in Sībawayhi's Kitāb," Zeitschift für Arabische Liguistik 8 (1982): 12-38, using biographical material as well, also concludes that Ibn Abī Ishạāq was the first real grammarian; cf. Henri Fleisch, Préliminaires, phonétique, morphologie nominale, vol. 1, Traité de philologie Arabe (Beirut: Imprimerie Catholique, 1961), 27-28; George Bohas, Jean-Patrick Guillaume and Djamel Kouloughli, The Arabic Linguistic Tradition (London and New York: Routledge, 1990), 1-2. Michael Carter, Sībawayhi (Oxford: I.B. Tauris, 2004), 18-19 (cf. Carter, "Les origines de la grammaire") remarks, however, that "[F]rom the meagre material in the Kitāb it would not be possible to deduce anything useful about what kind of 'grammarian' he might have been."

7 Biographies of Ibn Abī Isḥāq in: Abū Ḥāmid Aḥmad b. Muḥammad b. Shaybān al-Tirmidhī, (Makhțūt farìd nafìs 'an) Marātib al-nahwwiyyīn, ed. Hāshim al-Ṭa“ān, al-Mawrid 3, no. 2 (1974): 139; Abū al-Ṭayyib, Marātib, 12-13; Shihāb al-Dīn Aḥmad b. 'Alī Ibn Ḥajar al-'Asqalānī, Kitāb Tahdhīb al-tahdhīb, 14 vols. (Beirut: Dār al-Fikr, 1984), 5:148; Muḥammad b. Ḥibbān b. Aḥmad Abī Ḥātim, Kitāb al-Thiqāt, 7 vols. (Hyderabad, 1973), 5:61; Shams al-Dīn Abū al-Khayr Muhammad b. Muḥammad al-Jazarī, Ghāyat al-nihāya fì țabaqāt al-qurrā̄, ed. Gotthelf Bergsträsser, 2 vols. (Cairo: Maktabat al-Khānjī, 1932-1935), 1:410; Jamāl al-Dīn Abū al-Hajjāj Yūsuf al-Mizzī, Tahdhīb al-kamāl fi asmā' al-rijāl, ed. Bashshār 'Awwād Ma'rūf, 35 vols. (Beirut: Mu’assasat al-Risāla, 1993), 14:305-308; al-Qifțī, Inbāh, 2:104-108; Ṣalāḥ al-Dīn Khalīl b. Aybak al-Ṣafadī, Kitāb al-wāfı bi-l-wafayāt, eds. various editors, 30 vols. (Beirut/Wiesbaden: Franz Steiner Verlag, 1962-2010), 17:186; al-Sīrāfì, Akhbār, 25-28; Jalāl al-Dīn 'Abd al-Raḥmān al-Suyūṭi, Bughyat al-wu'āt fì țabaqāt al-lughawiyyīn wa-l-nuhāat, ed. Muhammad Abū al-Fạ̣l Ibrāhīm, 2 vols. (Cairo: Dār al-Fikr, 1979), 2:42; Abū al-Mahāsin al-Mufaḍ̣al b. Muḥammad al-Ma'arrī al-Tanūkhī, Ta’rīkh al-'ulamä’’ al-naḥwiyyīn min al-Bașriyyīn wa-l-Küfiyyīn wa-ghayrihim, ed. 
tioned in Sībawayhi's Kitāb. ${ }^{8}$ Ibn Abī Isḥāq was fervently anti-Arab (ța'ana lArab), we are told, and openly disgraced anyone - specifically the famous Arab poet al-Farazdaq (d. ca. 114/732) whose poetry he nevertheless transmittedwho committed lahn (solecism). ${ }^{9}$ He died in Basra at the age of 88 around the year 125/743 and was buried there. This is more or less all that we know about his life.

As to Ibn Abī Ishāà's scholarly activities, he reportedly systematised the study of the Arabic language and, furthermore, laid the foundations for what would later become explanatory — as opposed to descriptive — grammar. Biographical reports credit Ibn Abī Isḥāq with three awāìl-ba'aja l-naḥw (1) wamadda l-qiyās (2) wa-sharaha l-ilal (3), "he made grammar known, extended qiyās, and explained the causes" - which do not directly concern real innovations in the strictest sense, but they do imply a consolidation of particular technical devices conceived before his time. Indeed, following the chronology of these reports, general interest in the study of the Arabic language and an exploration of ways to do so had led to a delineation of grammar and the introduction of qiyās, the use of analogy to formulate grammatical rules. ${ }^{10}$ With Ibn Abī Ishāq's contribution to the field, it seems that a crucial point in the development of the Arabic linguistic tradition had been reached-hence the rationale for focusing on him here and accepting the awäil reports that also make this claim.

But Ibn Abī Ishāa did not operate in a vacuum: The biographical tradition of grammarians identifies nine people who were active in grammar in the period up to Ibn Abī Ishāà's death in the year 125/743. Moreover, if we take the period up to 166/785 into account — a period that includes Ibn Abī Isḥāq's studentsforty grammarians in all are mentioned by the grammatical biographical dictionaries. These numbers indicate that Ibn Abī Isḥāq was part of a larger social and intellectual environment that offered various opportunities to contribute to the development of scholarly activities in the study of the Arabic language.

'Abd al-Fattāḥ Muḥammad al-Ḥulw (Riyad: Dār al-Hilāl, 1981), 152-154; Abū Bakr Muhammad b. al-Ḥasan al-Zubaydī, Țabaqāt al-naḥwiyyīn wa-l-lughawiyyīn, ed. Muḥammad Abū al-Faḍl Ibrāhīm (Cairo: Dār al-Macārif, 1973), 31-33.

8 He is mentioned seven times in Kitāb Sïbawayhi (according to Carter, Sïbawayhi, 18-19, as an indirect informant).

9 See, e.g., al-Qifțī, Inbāh, 2, 106; Talmon, "Naḩwiyyūn in Sībawayhi's Kitāb," 3o, suggests that Ibn Abī Isḥāq's and 'Īsā b. 'Umar's attacking the Arabs is to be interpreted "as reluctance to accept the usages of native speakers as authoritative for their linguistic studies."

Bernards, "Pioneers of Arabic," 208-209. 
Stated differently, Ibn Abī Isḥāq belonged to a group of people who related to each other and, as such, constituted a social network. Ibn Abī Isḥāq's position in the Arabic linguistic tradition will shortly be studied through an analysis of his broader social and scholarly network. Information taken from biographical dictionaries of grammarians is used in this article to reconstruct, in a diagram, all of Ibn Abī Isḥāq's social contacts."1

\section{Selection of Ibn Abī Isḥāq's Network and the Method of Social Network Analysis}

The first step to be taken in order to establish a person's social relationships with others is to collect as much biographical data as possible about the person involved - in this case Ibn Abī Ishạa — as well as information about those who we are told had a relationship with him. I systematically went through the classical Arabic biographical dictionaries and identified the following groupings: (1) Ibn Abī Ishāâ's teachers and students; (2) the teachers and students of Ibn Abī Ishạā's teachers and students; and, to further canvass the network, (3) Ibn Abī Isḥāq's contacts outside grammarians' circles. In all, I discovered thirteen direct contacts and twelve indirect contacts. These are listed below in Table 1.1 (chronologically ordered within each grouping).

A methodological approach to examine Ibn Abī Isḥāq's relations is Social Network Analysis. A way to visualise relationships within a network is by drawing a diagram that depicts people as dots $(\bullet)$ — technically called the "nodes" of the network. These "nodes" are connected by lines that represent the relations between people. Such a diagram is called a "sociogram." The number of nodes

11 The data for this study are derived from the grammarians' database of the Ulama Project containing information on all known grammarians who were active prior to the year $400 / 1000$ and identified by their inclusion in one of the biographical dictionaries of grammarians (e.g., al-Tirmidhī (d. ca. 250/864), Marātib al-naḥwiyyinn; Abū Ṭayyib alLughawī (d. 351/962), Marātib al-naḥwiyyīn; al-Sīrāfì (d. 368/979), Akhbār al-naḥwiyyīn al-Bașriyyìn; al-Zubaydī (d. 379/989), Tabaqāt al-naḩwiyyinn wa-l-lughawiyyinn). The total number of grammarians active during this entire period is around seven hundred. This database also includes information on teacher-student relationships as well as the lines of transmission of grammatical works. For a general description of the Ulama Project, see Monique Bernards and John Nawas, "A Preliminary Report of the Netherlands Ulama Project (NUP): The Evolution of the Class of 'Ulamā' in Islam with Special Emphasis on the Non-Arab Converts (Mawālī) from the First Through Fourth Century A.H.," in Law, Christianity and Modernism in Islamic Society, eds. Urbain Vermeulen and Jan M.F. van Reeth (Leuven: Peeters, 1998), 97-107. 
Direct contacts: His teachers
1 Nașr b. ‘̄sṣim
d. $89 / 708$
2 Maymūn al-Aqran
d. ca. $99 / 717-718$
3 Yahyā b. Ya'mar
d. ca. 106/724-725

Direct contacts: His students
4 '̄̄sā b. 'Umar
d. $149 / 766$
5 Abū 'Amr b. al-'Alā'
d. ca. $157 / 774$
6 Maslama b. 'Abd Allāh
d. ca. $159 / 775^{-776}$
7 Bakr b. Habīb
d. ca. $159 / 775^{-776}$
8 Hammād b. Salama
d. $167 / 783-784$

Direct contacts: Outside grammarians' circles
9 Zayd b. al-Hāāith
d. ca. $90 / 709$
10 Ibn Sīrīn
d. $110 / 728$
11 al-Farazdaq
d. $114 / 732$
12 Qatāda
d. ca. $117 / 735$
13 Bilāl b. Abī Burda
d. $122 / 740$

Indirect contacts: Tabaqa of teachers
14 Abū Hurayra
d. $58 / 679$
15 Ibn 'Abbās
d. $68 / 687-688$
16 Abū al-Aswad
d. ca. $69 / 688-689$
17 'Anbasa al-Fīl
d. ca. $99 / 717-718$
18 Ibn Hurmuz
d. $117 / 735$

Indirect contacts: Tabaqa of students
19 Khalīl b. Aḥmad
d. ca. $170 / 786$
20 Sībawayhi
d. ca. $180 / 796$
21 Yūnus b. Habīb
d. $182 / 798$
22 al-Kisā'̄̄
d. $183 / 799$
23 Abū Ubayda
d. ca. $210 / 825$
24 al-Așmāī
d. $213 / 829$
25 al-Anșārī
d. $215 / 830$ 
and the frequency of lines which connect the nodes in a sociogram show us the relational fabric of the group. ${ }^{12}$

Additionally, Social Network Analysis uses several measures to analyse various aspects of a network. For instance, from patterns in the configuration of the nodes and the connecting lines, one can detect "centrality" versus "isolation." Centrality is when one node has a central position and is connected to several other nodes which may or may not be directly related to each other. However, when many nodes are interrelated and connected to one node in a central position, we speak of a "block." Isolation is a situation in which one single node is connected to another node that is embedded in the network. "Paths," another facet of a network, indirectly connect nodes to each other through a distinct sequence of lines within the network. There are other measures as well in Social Network Analysis, but for this particular study, only the four just mentioned — centrality, blocks, isolation, and paths-are required..$^{13}$

\section{Sociogram of Ibn Abī Isḥāq's Network}

Ibn Abī Isḥāq's direct contacts are displayed in a sociogram (Figure 1.1).

Figure 1.1 depicts, for obvious reasons, the perfect centrality of an egocentric network. Ibn Abī Isḥāq's network spans the lifetime of Nașr b. 'Āṣim (d. 89/708), at the top of the sociogram, up to Hammād b. Salama (d. 167/783-784), at the bottom. If one takes into account that the dates mentioned are death dates, Figure 1.1 shows about 120 years of intellectual life, ranging from ca. $49 / 669$ to $167 / 783-784$.

Figure 1.2 is the sociogram of Ibn Abī Isḥāq's complete network, including his indirect contacts as well. The time span is thus expanded by another 70 years, from around $18 / 639$ to $215 / 83$.

12 On the method of Social Network Analysis in general, see John Scott, Social Network Analysis: A Handbook. 2nd edition (Beverley Hills and London, 2000); Stanley Wasserman and Katherine Faust, Social Network Analysis: Methods and Applications, Structural Analysis in the Social Sciences 8 (Cambridge: Cambridge University Press, 1997). For Social Network Analysis in historical research, see B.H. Erickson, "Social Networks and History: A Review Essay," Historical Methods 30 (1997): 149-157. For the use of Social Network Analysis in the study of the Arabic linguistic tradition, see Monique Bernards, "Grammarians' Circles of Learning: A Social Network Analysis," in 'Abbasid Studies II, ed. John Nawas (Leuven: Peeters, 2010), 143-164.

13 For other measures, see Bernards, "Grammarians' Circles of Learning." 


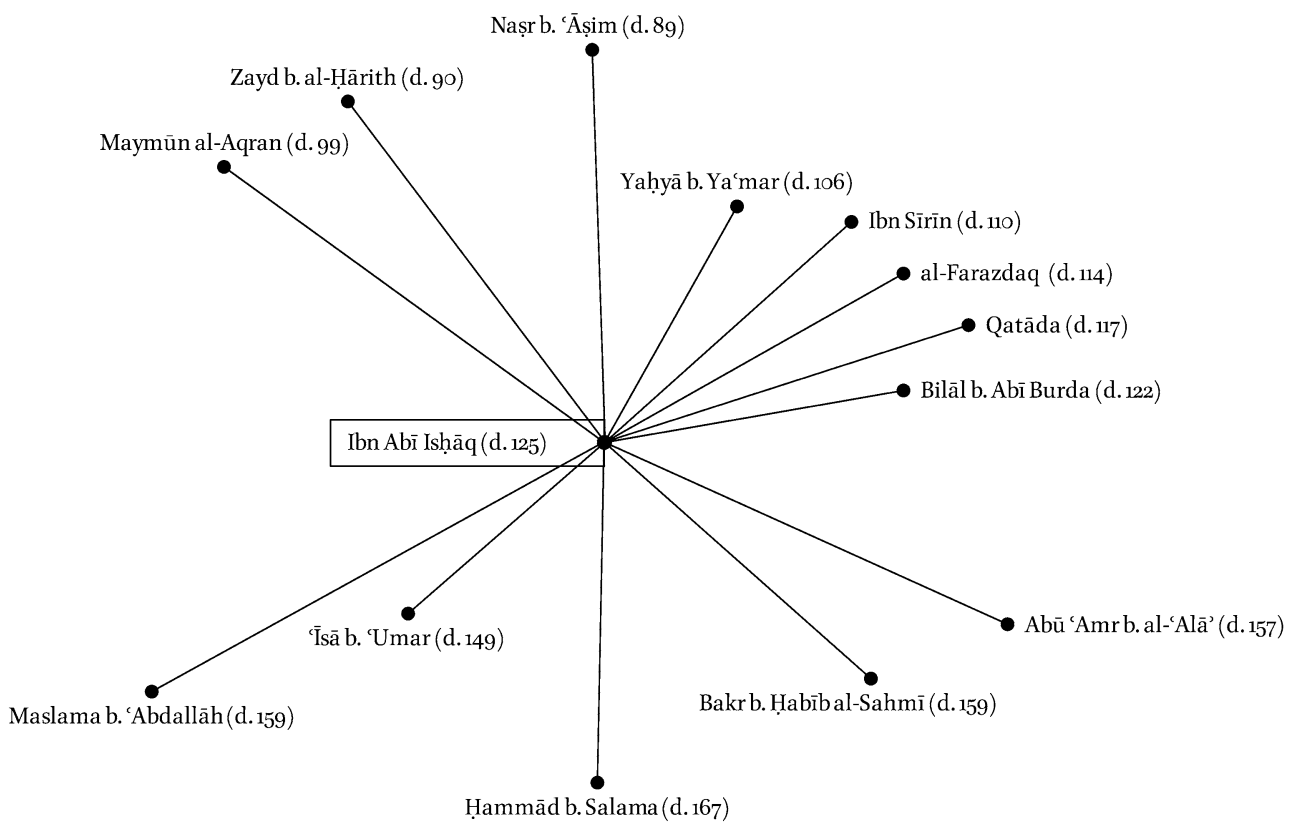

FIGURE 1.1 Sociogram of Ibn Abī Isḥāq's direct contacts

A first general inspection of the sociogram shows that Ibn Abī Isḥāq is firmly embedded in a large network. His position is one of centrality and it has links to three different blocks (marked by circles in the sociogram of Figure 1.2) in which the positions of Yahyā b. Ya'mar, 'Īsā b. 'Umar, and Abū 'Amr b. al'Alā' show centrality as well-their nodes are connected to many other nodes which, in turn, relate to each other. Only one out of the thirteen lines directly linked to Ibn Abì Ishạāq ends in a single node. This is an example of isolation: the node of Zayd b. al-Ḥārith. ${ }^{14}$

At the top of the sociogram we find three well-known figures: Abu al-Aswad al-Du'ali (d. 69/688-689), poet, littérateur, and traditionist (muhaddith), judge in Basra; the alleged founder of Arabic grammar as we have already mentioned above; Abū Hurayra (d. ca. 58/679), a famous Companion of the Prophet, celebrated for passing on more traditions (hadiths) than any other Compan-

14 For the sake of clarity, the network depicted in Figure 1.2 leaves out relations between lexicographers like al-Khalīl, Yūnus and Abū 'Amr. Fuat Sezgin, Geschichte der arabischen Schrifttums: Band IX Grammatik bis ca. 430 H. (Leiden: Brill, 1984), 36, 43, 48, identifies additional relations between Ibn Abī Isḥāq on the one hand, and Hārūn b. Mūsā (d. 17o/786) and al-Akhfash al-Akbar (d. 177/793) on the other, which are not mentioned in the sources used for this article. 


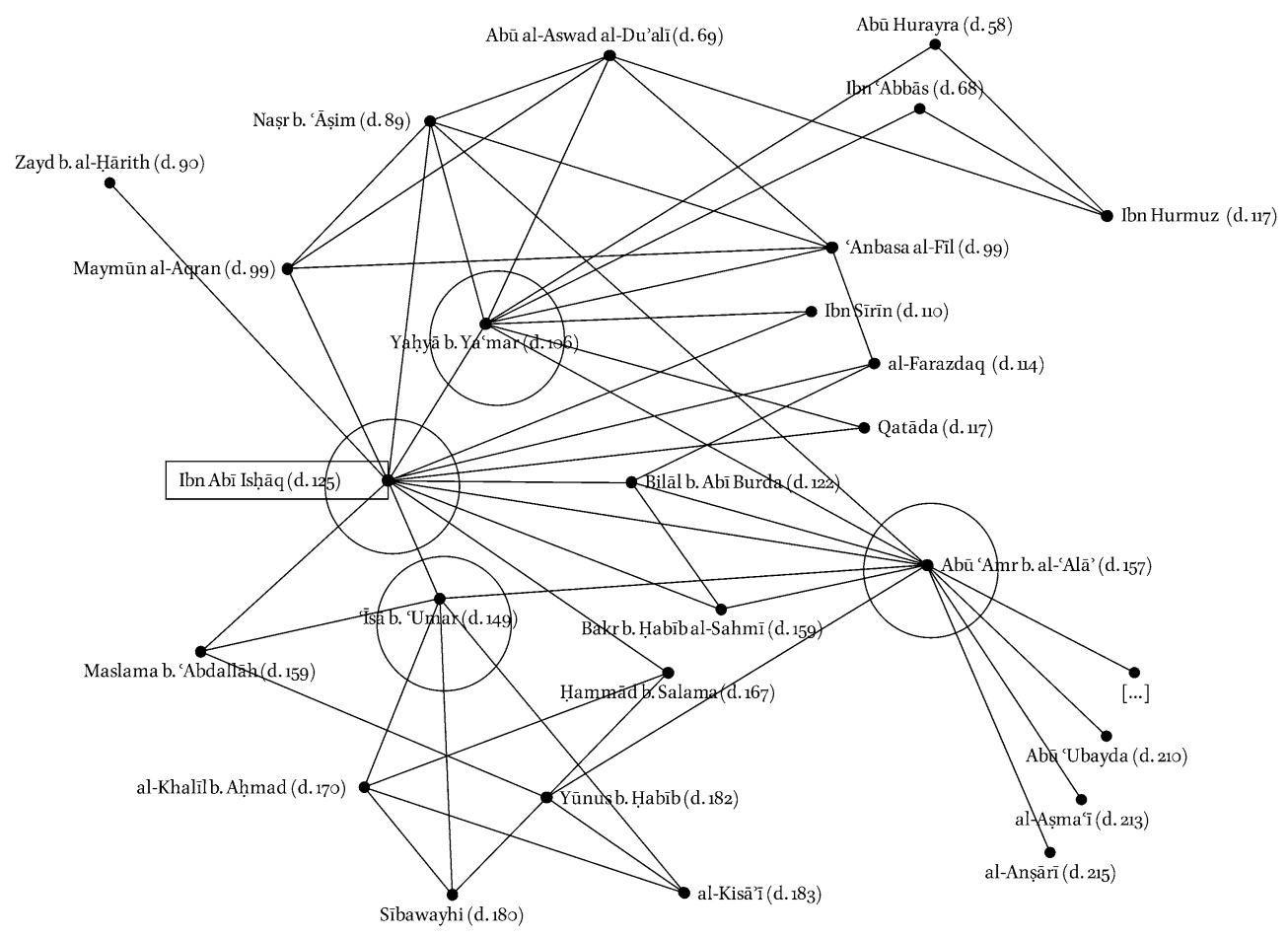

FIGURE 1.2 Sociogram of Ibn Abī Ishạa's complete network (showing blocks)

ion;15 and 'Abbās (d. 68/686-688), paternal cousin and Companion of the Prophet, traditionally considered one of the greatest scholars of the first generation of Muslims, having excelled in almost all fields of knowledge, especially in qurānic studies. ${ }^{16}$

These three men personify Islamic sciences-to-be, later known as grammar (naḩw), hadith, and qurānic reading (qiräa). They have two students in common: The first one, located at the right hand side of the sociogram, is the rather isolated Ibn Hurmuz (d. 117/735), a Medinan traditionist who was reportedly the first to practice the study of Arabic grammar in Medina. Towards the end of his life, he moved to Alexandria where he died. ${ }^{17}$ The second common stu-

15 Gautier H.A. Juynboll, "Abū Hurayra," in Encyclopaedia of Islam THREE, Yearbook 2007 (Leiden: Brill, 2019), 133-136.

16 Claude Gilliot, “Abdallāh Ibn 'Abbās," in Encyclopaedia of Islam THREE, Yearbook 2012 (Leiden: Brill, 2019), 41-55.

17 'Abd al-Raḥmān b. Hurmuz al Madanī: al-Suyūṭī, Bughya, 2, 91; al-Sīrāfì, Akhbār, 21-22; al-Zubaydī, Ṭabaqāt, 26; al-Qifțī, Inbāh, 2:172-173. See Rafael Talmon, "An Eighth-Century Grammatical School in Medina: The Collection and Evaluation of the Available Material," 
dent of this threesome is Yahyā b. Yacmar (d. 106/724-725), generally praised for his excellent command of Arabic. He was a traditionist and jurist (faqīh) who worked as a judge in Basra, but after having aggravated al-Hajjāj b. Yūsuf (d. 95/714), the special military deputy of the Umayyad caliph 'Abd al-Malik (r. 65-86/685-705), he was sent to become secretary (kātib) in Khurasan where he died. ${ }^{18}$

Yahyā b. Ya'mar has a firm place in the network of Abū al-Aswad's other students: 'Anbasa al-Fill (d. ca. 99/717-718), who was specialised in poetry (shir $)$ and was furthermore noted for his eloquence and personal charm. ${ }^{19}$ 'Anbasa had no direct connection with Ibn Abī Isḥāq, but, like Ibn Abī Isḥāq, he transmitted poetry from al-Farazdaq (d. 114/732), who was, together with Jarīr and al-Akhțal, one of the best Arab poets of all time. ${ }^{20}$ 'Anbasa's friend Maymūn alAqran (d. ca. 99/717-718) was a less famous teacher of Ibn Abī Isḥāq. ${ }^{21}$ Naṣr b. 'Āṣim al-Laythī (d. 89/708), on the other hand, was a well-known traditionist, qur'ānic reader and jurist. ${ }^{22}$

The sociogram of Figure 1.2 has a direct line connecting Nașr b. 'Āṣim with Ibn Abī Isḥāq as well as one that goes through Yahyā b. Yámar. Both Naṣr b. 'Āṣim and Yahyā b. Ya'mar turn out to be influential teachers of Ibn Abī Ishāā.

Ibn Abī Ishạāq is also scholarly connected to his own father, Zayd b. alḤārith (d. ca. 9o/709) - in isolation located top left in the sociogram-from whom he transmitted hadith. ${ }^{23} \mathrm{He}$ also transmitted hadith from Ibn Sīrin (d. 110/728), a famous traditionist and jurist, son of a slave of Anas b. Mālik (d. 93/712) and a cloth merchant who became the first renowned Muslim inter-

Bulletin of the School of Oriental and African Studies 48 (1985): 224-236, for a hypothesis on the existence of a Medinan center of grammar, founded by Ibn Hurmuz.

18 The sources mention several possibilities for Yahyā b. Ya'mar's date of death ranging from 83/702 to 129/746-747; see al-Suyūțī, Bughya, 2:345; al-Sīrāfì, Akhbār, 22-23; al-Zubaydī, Ṭabaqāt, 27-29; al-Qifțī, Inbāh, 4:24-27.

19 'Anbasa reportedly obtained the nickname al-Full, "the Elephant," from his father who apparently made a fortune from taking care of the elephant of the Umayyad governor of Basra, Ziyād b. Abīhi (d. 55/673). Biographical information is found in al-Suyūṭī, Bughya, 2:233; al-Sīrāfī, Akhbār, 23-24; al-Zubaydī, Țabaqāt, 29-30; al-Qifțī, Inbāh, 2:381382 .

20 See Nefeli Papoutsakis, "al-Farazdaq," in Encyclopaedia of Islam THREE, Yearbook 2012 (Leiden: Brill, 2019), 467-471.

21 Abū 'Abd Allāh Maymūn al-Aqran: al-Suyūțī, Bughya, 2:3og; al-Sīrāfì, Akhbār, 25; al-Zubaydī, Țabaqāt, 3o; al-Qifțī, Inbāh, 3:337-338.

22 Nașr b. 'Āṣim al-Laythī, see al-Suyūțī, Bughya, 2:313; al-Sīrāfī, Akhbār, 21; al-Zubaydīi, Ṭabaqāt, 27; al-Qifțī, Inbāh, 3:343-344.

23 No biographical details were found on Zayd b. al-Ḥarith (the date of his death is estimated on the basis of his position in the network of his son Ibn Abī Abī Isḥāq). 
preter of dreams. ${ }^{24}$ From Ibn Sīrī's student, the traditionist Qatāda b. Di'āma al-Sadūsì (d. ca. 120/738) — who was known for his knowledge about genealogies, lexicography, historical traditions, and qur'ānic readings—Ibn Abī Isḥāq transmitted hadith as well. ${ }^{25}$

Ibn Abī Ishạāq reportedly also had contact with Bilāl b. Abī Burda (d. 122/740), grandson of the Prophet's Companion Abū Mūsā al-Ash'arī (d. ca. 48/668); like his grandfather, he was governor of Basra, and celebrated at the time for gathering poets and littérateurs in his salon ${ }^{26}$ - as shown by the lines in Figure 1.2 that connect him with al-Farazdaq and Abū 'Amr b. al-'Alā'.

Five lines connect Ibn Abī Ishāa with his five students. Not much is known about Bakr b. Habīb al-Sahmì (d. ca. 159/775-776), except that he hailed from an Arab family of traditionists. Maslama b. 'Abd Allāh (d. ca. 159/775-776) was a nephew of Ibn Abī Ishāa, a traditionist who lived in Basra until the end of his life when he moved to Mosul to become the educator of caliph al-Manșūr's (r. 136-158/754-775) son. ${ }^{27}$ Bakr b. Habīb and Maslama b. 'Abd Allāh are the lesser known students of Ibn Abī Isḥāq.

'Tsā b. 'Umar (d. 149/766), on the other hand, studied qur'ānic reading under Ibn Abī Ishạa and became very influential in the study of Arabic grammar. Some say that his book entitled al-Jämic (literally, "comprehensive, extensive") served as a basis for Sībawayhi's Kitāb. He reportedly wrote many books, none of which has survived. 'İsā b. 'Umar was as fiercely anti-Arab as was his teacher Ibn Abī Isḥāq, and the sources note several occasions on which he discussed the use of ungrammatical Arabic (laḥn, solecism). It is recounted that 'Īsā b. 'Umar had a serious speech impediment and sounded like an Indian. ${ }^{28} \mathrm{Abu}$ 'Amr b.

24 See Toufic Fahd, "Ibn Sirīn," in Encyclopaedia of Islam, 2nd ed. (Leiden: Brill, 1971), 3:947948.

25 See Charles Pellat, "Katāda b. Di'āma," in Encyclopaedia of Islam, nnd ed. (Leiden: Brill, 1978), 4:748. According to al-Qifțī (Inbāh, 2, 107-108), Qatāda and Ibn Abī Isḥāq died on the same day and all nobles (ashrāf) and specialists of adab attended Ibn Abī Isḥāq's funeral while the pious people and the legal scholars ( fuqahā') went to bury Qatāda. Inasmuch as the sources have alternative years of death for Ibn Abī Ishâa — he died between $120 / 738$ and $129 / 747-748$ - his and Qatāda's dates mentioned in the sociogram are not the same.

26 Cf. Charles Pellat, Le milieu bașrien et la formation de Ğăhiz (Paris: Adrien-Maisonneuve, 1953), 157, 275, 288.

27 Bakr b. Ḥabīb al-Sahmī: al-Suyūțī, Bughya, 1:462-463; al-Zubaydī, Ṭabaqāt, 46; al-Qifțī, Inbāh, 1:279-28o. Maslama b. 'Abd Allāh al-Fihrī: al-Suyūṭī, Bughya, 2:287; al-Zubaydī, Țabaqāt, 45; al-Qifțī, Inbāh, 3:262.

28 'Īsā b. 'Umar al-Thaqafì: al-Suyūṭī, Bughya, 2:237-238; al-Sīrāî̀, Akhbār, 31-33; al-Zubaydī, Țabaqāt, 40-45; al-Qifțī, Inbāh, 3:373-377. 
al-Alā' (d. 157/774), a famous qur'ānic reader, was a versatile scholar involved in many fields of endeavour. Reports on Abū 'Amr include a good many discussions about mawāli and Arabs and who knows the best Arabic. ${ }^{29}$ Finally, Ḥammād b. Salama (d. 167/783-784), an illustrious traditionist and jurist who acted as mufti in Basra, was also trained by Ibn Abī Isḥāq. ${ }^{30}$

Moving on to the bottom part of the sociogram of Figure 1.2, we see connecting lines to famous and influential scholars of the next generation. One line goes from Ibn Abī Isḥāq through 'Īsā b. 'Umar to al-Khalīl b. Aḥmad (d. ca. 170/786), author of the first Arabic dictionary (Kitāb al-'Ayn), and furthermore specialised in prosody and astrology, who is said to have deciphered Greek on his own. ${ }^{31}$ Al-Kisā̄i (d. 183/799), of Persian descent, is reckoned amongst the proponents of the Kufan school of grammar-he is the only representative of the Kufans in Ibn Abī Isḥāq's overall Basran network. ${ }^{32}$ Al-Kisā'ī was also active in qurānic studies: his qirāa $a$ is one of the seven canonical Readings of the Qur'ān. ${ }^{33}$ The line ends at Sībawayhi (d. ca. 18o/796), Persian author of the first full-fledged grammar of Arabic, the famous Kitäb. ${ }^{34}$

Another line connects Ibn Abī Ishạāq through Abū 'Amr b. al-Alā' to Yūnus b. Habīb (d. 182/798), from Jubbal in present-day India, who specialised in poetry alongside qurānic studies. ${ }^{35} \mathrm{He}$ is also connected to Abū 'Ubayda (d. ca. 210/825) who hailed from a Jewish family originating in Bajarwan (located in Shirvan, a region in the eastern Caucasus) and who is said to have fiercely hated the Arabs. ${ }^{36}$ Another line goes to al-Așma'ì (d. 213/829), a stingy Arab

29 Abū 'Amr b. al-Alā': al-Suyuțī, Bughya, 2:231-232; al-S̄̄rāfī, Akhbār, 28-31; al-Zubaydī, Țabaqāt, 35-40; al-Qifțī, Inbāh, 4:131-139.

30 Ḥammād b. Salama: al-Suyuțī, Bughya, 1:548-549; al-Sīrāfì, Akhbār, 42-44; al-Zubaydī, Țabaqāt, 51; al-Qifțì, Inbāh, 1:364-365.

31 al-Khalīl b. Aḥmad: al-Suyūṭī, Bughya, 1:557-56o; al-Sīrāfì, Akhbār, 38-40; al-Zubaydī, Țabaqāt, 47-51; al-Qifțī, Inbāh, 1:376-382.

32 The development of Arabic language studies is traditionally and, probably in retrospect, characterised by the formation of two schools of grammar, a Basran and a Kufan school. Not presented in the sociogram of Figure 1.2 is the Basran imprint of Ibn Abī Isḥāq's network.

33 'Alī b. Ḥamza al-Kisā’ī: al-Suyuṭī, Bughya, 2:162-164; al-Zubaydī, Țabaqāt, 127-13o; al-Qifṭī, Inbāh, 2:256-274.

34 Sībawayhi: al-Suyūṭī, Bughya, 2:229-23o; al-Sīrāfī, Akhbārr, 48-5o; al-Zubaydī, Ṭabaqāt, 6672; al-Qifțī, Inbāh, 2:346-36o.

35 Yūnus b. Ḥabīb: al-Suyūṭī, Bughya, 2:365; al-Sīrāfì, Akhbār, 33-37; al-Zubaydī, Ṭabaqāt, 5153; al-Qifțī, Inbāh, 4:74-78.

36 Abū 'Ubayda Ma'mar b. al-Muthannā: al-Suyūțī, Bughya, 2:294-296; al-Sīrāfì, Akhbārr, 6771; al-Zubaydī, Țabaqāt, 175-178; al-Qifțī, Inbāh, 3:276-288, calling him a "shu'ūbì." 
and polymath, we are told, who specialised in a broad range of studies. ${ }^{37}$ Finally, Abū Zayd al-Anșāin (d. 215/83o), a Shiite and an all-round scholar, like al-Aṣmaīī, who is said to have been very handsome. ${ }^{38}$

With Sïbawayhi at the bottom of the sociogram, we are on solid ground: we have his extant work that marks a fully developed and distinct scholarly disciplineArabic grammar. Let us now try and trace back the paths of the various disciplines in Ibn Abī Ishạā's network. This analysis will provide us with insight into how these disciplines have emerged. Tracing back sheds light on otherwise "dark" paths.

\section{$5 \quad$ Intellectual Specialisations}

Biographical dictionaries of grammarians offer information about intellectual endeavours pursued by the individual scholar besides language studies. Table 1.2 lists all these endeavours in a matrix for the group of scholars that operated within Ibn Abī Isḥāq's network.

For the sake of clarity, the specialisations in the table are classified into three broad categories - religious, linguistic, and secular:

"Religious" (left hand side of the table):

- Hadith, collection and transmission of traditions

- Qiräa a, reading of the qurānic text

- Tafsìr, qurānic exegesis

- Figh, Islamic jurisprudence

"Linguistic" (in the middle columns):

- Arabiyya, study of the Arabic language

- Naḥw, grammar, grammatical studies of Arabic

- Lugha, Arabic lexicography (including the subfield gharïb, about rare and uncommon words and expressions) ${ }^{39}$

37 al-Așma'ī 'Abd al-Malik b. Qurayb: al-Suyūțī, Bughya, 2:112-113; al-Sīrāfī, Akhbār, 58-67; alZubaydī, Țabaqāt, 167-174; al-Qifțī, Inbāh, 2:197-205.

38 Abū Zayd al-Anșārī Sa īd b. Aws: al-Suyūṭī, Bughya, 1:582-583; al-Sīrāfì, Akhbār, 52-57; alZubaydī, Tabaqā $t$, 165-166; al-Qifțī, Inbāh, 2:30-35.

39 Notably the study of uncommon words and expressions in the Qur'ān (gharīb al-qur'ān) and hadith (gharīb al-hadìth). 


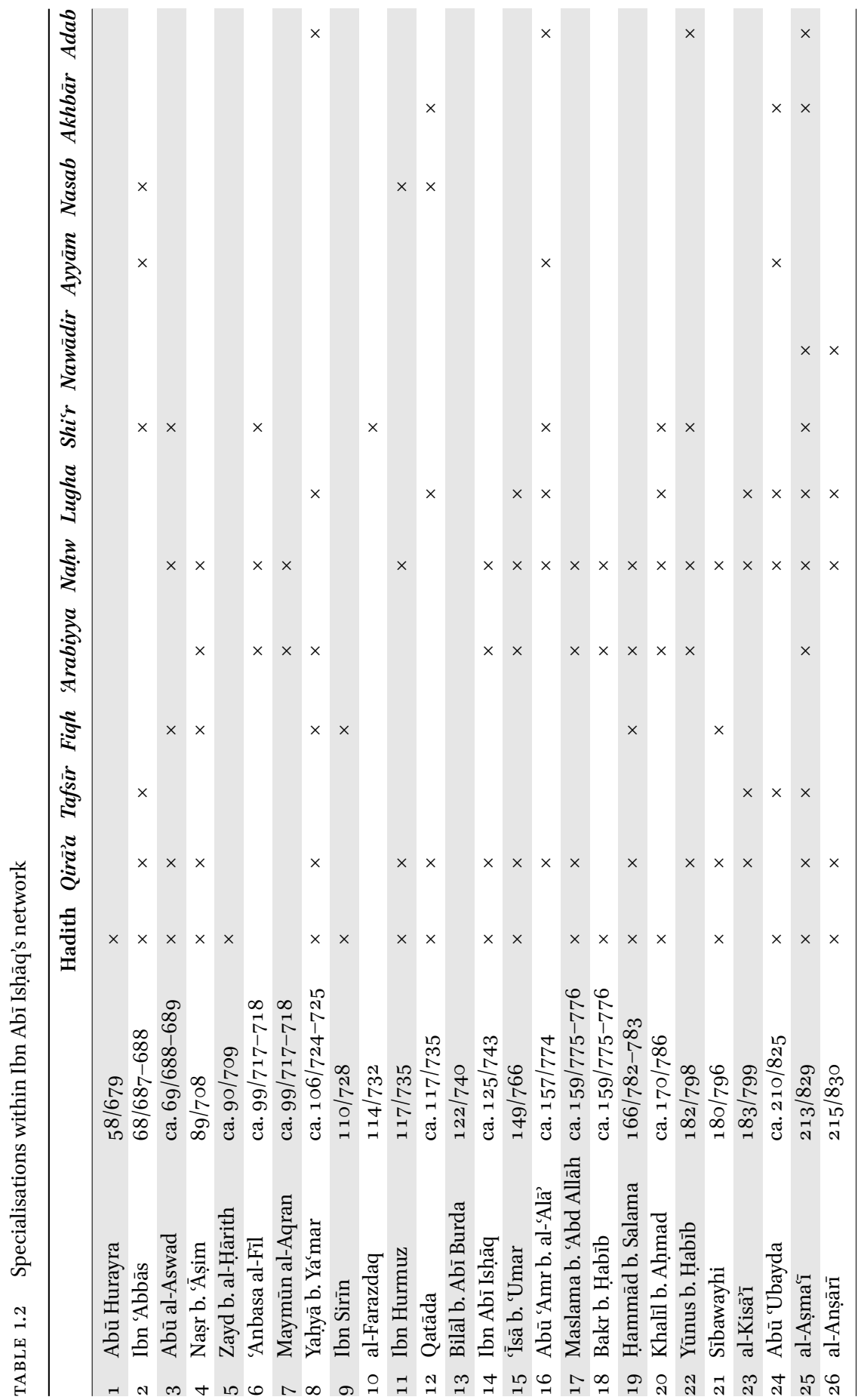


"Secular" (right hand side of the table):

- Shirr, either composing or collecting, transmitting, explaining poetry

- Nawādir, collection and transmission of entertaining stories

- Ayyām al-Arab, collection and transmission of Bedouin (heroic) stories

- Nasab, genealogy

- Akhbār, collection and transmission of historical stories ${ }^{40}$

- Adab, body of secular knowledge that can be transmitted by someone qualified as mu'addib ${ }^{41}$

A bird's eye view of Table 1.2 offers some remarkable general observations. First, the left hand side of Table 1.2 immediately shows that almost all scholars were in one way or another involved in the collection and/or transmission of hadiths. Qur'ānic exegesis (tafsir), on the other hand, is a late phenomenon and Islamic jurisprudence ( figh) only sporadically appears in the table covering this period. ${ }^{42}$ We also discern that the emergence and development of the study of the reading(s) of the qurānic text (qiräa) went hand in hand with Arabic language studies ('Arabiyya, nahw, lugha). All scholars from Ibn Abī Ishạa onwards were involved in Arabic grammar ( $n a h ̣ w)$, while the more general study of Arabic ('Arabiyya) has almost disappeared by the end of the period. Arabic lexicography (lugha) and the study of rare words or expressions (gharib) seem to follow the pattern of the secular fields of endeavour (on the right hand side of Table 1.2), gradually filling in the matrix as we move toward the end of the period. In all, four scholars were specialised in adab; they are found in the last column of Table 1.2: Yahyyā b. Yámar (teacher of Ibn Abī Isḥāq), Abū 'Amr b. al-'Alā' (student of Ibn Abī Ishāq), Yūnus b. Ḥabīb and al-Aṣma'ī (two students of Abū 'Amr b. al-'Alā').

Combining now data from Table 1.2 with a more detailed scrutiny of the sociogram of Ibn Abī Isḥāq's network (Figure 1.2), we see two clear paths (i.e., connecting lines that are directional and here represent causal sequences) between the four major blocks we identified earlier. Figure 1.3 zooms in on these two paths or lines of transmission, showing directional relations of the nucleus of Ibn Abī Ishāā's network with a focus on "linguistic" specialisations as defined above. Additionally, for reasons that will be explained later, adab is added to the listing of specialisations for each individual where appropriate.

40 See Roberto Tottoli's contribution in this volume.

41 I thank James Montgomery for providing me with this working definition of adab (personal conversation, Istanbul, August 14, 2014).

42 For the co-development of grammar and jurisprudence, see Carter, "Les origines de la grammaire." 


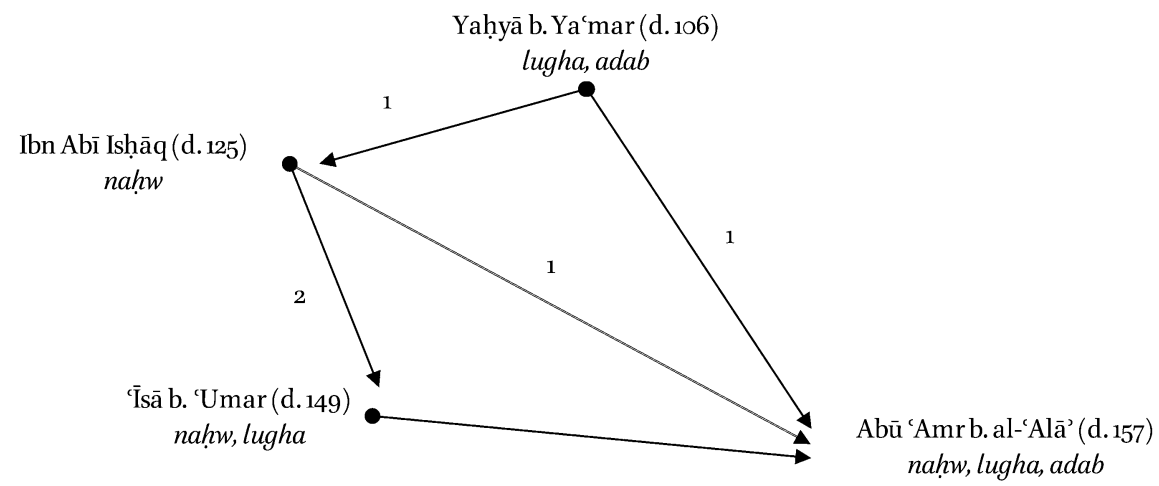

FIGURE 1.3 Detail of Ibn Abī Ishạa's network (showing paths

The three blocks, in which the positions of Ibn Abī Isḥāq, Yahyā b. Ya'mar, and 'İsā b. 'Umar are central, are all connected to Abū 'Amr b. al-Alä' who incorporated all specialisations received from his teachers: nahww, lugha, and adab. If we now extend this diagram to include the following two generations, the importance of the blocks and paths becomes evident.

On the one hand, we see a clear path of three steps leading from Yahyā b. Ya'mar, through Ibn Abī Ishạa and 'Īsā b. 'Umar, to Sībawayhi, the grammar specialist par excellence. On the other hand, an adab path leads in two steps as well from Yahyā b. Ya'mar (and Ibn Abī Isḥāq) through Abū 'Amr b. al-'Alā' and al-Așma'ī to the preeminent $a d a b$ writer, al-Jāhị (d. 255/869). With Sībawayhi's book on grammar and the $a d a b$ works of al-Jāhiz, we have reached solid ground in terms of extant works in the two distinct disciplines.

Language studies in general and Arabic grammar in particular are early developments in the context of Arabic-Islamic scholarly activities. The need for a good understanding of the Arabic text of the Qurān and an awareness of a radically changing use of Arabic due to a rapidly expanding empire and a growing number of non-native speakers led to an interest in language studies and sped up the development of grammar as a discipline. Within two centuries from the beginning of the Islamic era, a fully-fledged grammar of Arabic came into existence, Kitāb Sībawayhi.

How grammar emerged and developed as a field within the context of Arabic language studies and how the earliest "professionals" in this discipline interconnected, has been studied here by using Social Network Analysis — a widely 


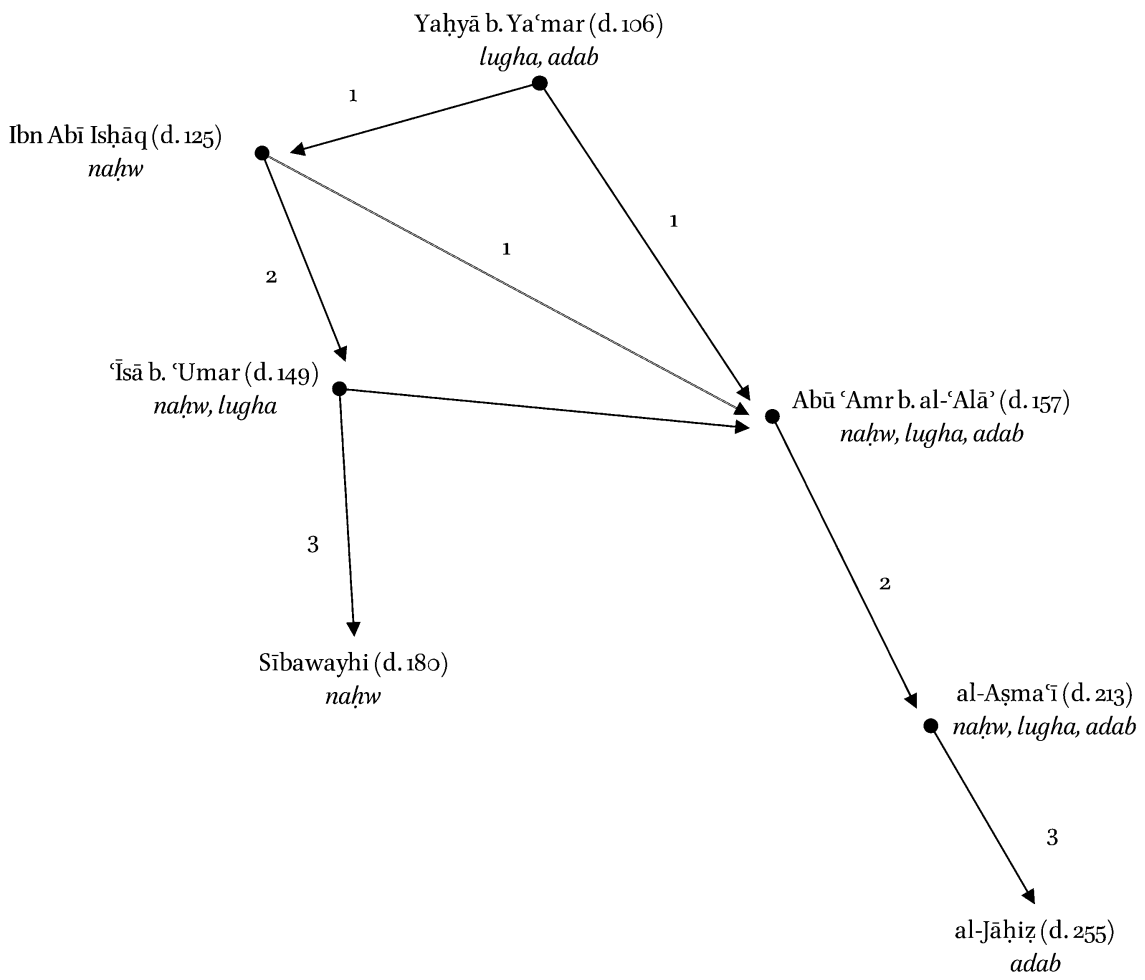

FIGURE 1.4 Detail of Ibn Abī Ishạā's network extended (showing paths

used method in the social sciences, but hardly applied in our field. More specifically, the method was used to identify and further clarify the relations within the network of one particular scholar, Ibn Abī Isḥāq, who died around the year 125/743. Based on our initial assumption that Ibn Abī Ishạāq played a pivotal role in the beginning of Arabic grammar, we selected him for a detailed scrutiny of his social and intellectual environment. From the biographical literature, information was collected on Ibn Abī Isḥāq's teachers and students and their respective contacts. Subsequently, these people were mapped in sociograms.

Inspection of the sociograms revealed that Ibn Abī Ishāq indeed held a central position in a network that was furthermore characterised by the existence of several blocks. These findings indicate a tightly interrelated network and lively social surroundings. We were able to identify two important paths or lines of transmission within the network revealing that both paths start with Yahyā b. Ya'mar, a scholar of the previous generation who died around the year 106/724725. One path leads in three steps from Yahyyā b. Ya'mar via Ibn Abī Isḥāq and 'İsā b. 'Umar to Sībawayhi who elaborately consolidated Arabic grammar in his 
Kitāb, while the other is a bridge, consisting of three steps as well, via Abü 'Amr b. al-'Alä' and al-Așma'ì, to the further development of $a d a b$ culminating in the works of the foremost adab writer of the classical period, al-Jāhiz (d. 255/869).

In other words, we have waded through unknown and uncharted territories to arrive at well-established disciplines which we are familiar with thanks to the fact that their writings are extant- unlike the earlier period. The application of Social Network Analysis using biographical information thus affords us insights that we miss relying solely on extant works. Suddenly and quite unexpectedly, scholars appear in central positions, assuming important roles in the development of certain fields. In the network of Ibn Abī Isḥāq it is Yahyā b. Ya'mar who holds a key position at the passageway for two distinct paths in the network leading to the crystallisation of grammar on the one hand and adab on the other. ${ }^{43}$

However, the lack of extant works prevents us from knowing exactly what kind of grammar or $a d a b$ was pursued at the time - we only know the outcome at the end of the paths. Before that time, they probably were not autonomous fields or part of a standard curriculum - that was to come later-but they did constitute the kernel of grammar as a later discipline, just like the kernel of adab existed at the time..$^{44}$ For an attempt to reconstruct the development from kernel to outcome, we have used information from the biographical dictionaries.

In our discussion of the intellectual specialisations pursued by the scholars in our network, we have seen that the more general study of Arabic ('Arabiyya) gradually disappears and that from Ibn Abī Isḥāq onwards all scholars were involved in nahw, which I have called "grammar proper." By the time we reach Sibawayhi, nahww, literally "way of speaking," had come to denote syntax as opposed to tașrīf, morphology. ${ }^{45}$ Moreover, as the awäil sources tell us, Ibn Abì Ishāa apparently laid down the foundations for a much later development of

43 In a different study (Bernards, "Grammarians' Circles of Learning," 163), I have already shown that the scholar al-Shaybānī (d. 209/824), fairly unknown as a grammarian, held a prominent position amongst the Kufan grammarians of the early third/ninth century.

44 See Wolfhardt Heinrichs, "The Classification of the Sciences and the Consolidation of Philology in Classical Islam," in Centres of Learning: Learning and Location in Pre-Modern Europe and The Near East, eds. Jan Willem Drijvers and Alasdair A. MacDonald (Leiden: Brill, 1995), 119-139. Heinrichs used original texts, i.e., list-literature from the fourth/tenth century that reflects the manner in which thinking about one's own specialisations was reconstructed. Regarding $a d a b$, he concludes that one has to go to later centuries for a more systematic description of $a d a b$ as autonomous field.

Åkesson, "Șarf." 
rationalisation of language by introducing the concepts of qiyās (analogy), and cilal (causes), to explain hierarchical relations between grammatical categories. ${ }^{46}$

The concept of adab, literally "good behaviour, good custom," is much harder to grasp. Adab is not only associated with a large variety of concepts and materials, but its meaning changes greatly over time as well. However, my working definition here- a body of secular knowledge that can be transmitted by someone qualified as mu'addib - incorporates two aspects that have been part and parcel of $a d a b$ from the very beginning. Adab has an element of education (implied in the term mu'addib, "educator") and it is set apart from 'ilm, religious knowledge. This is more or less in accordance with the use of the term in canonical hadith where the books of adab treat rules for good social behaviour and correct usage of Arabic contrasted with lahn (solecism). ${ }^{47}$ Al-Jāhiz, situated at the end of the $a d a b$ path in our network, is included in the kind of $a d a b$ that is first and foremost characterised by eloquence in writing, particularly of letters and essays $($ rasāali $) .{ }^{48}$

In the context of intellectual history-based on data taken from biographical sources-Yahyā b. Ya'mar is a key figure in the emergence and development of both grammar and $a d a b$. He is a pioneer of grammatical studies, considered the best grammarian of his time and reportedly elaborated Abū al-Aswad's initial notes on grammar. As for $a d a b$, his excellent command of the Arabic language and his eloquence were praised. He is mentioned amongst the fusaha $\bar{a}$ ' $a l$-Arab, those skilled in the use of Arabic prose which he had learned from his father. Yahyā's style and wit were recognised in particular by al-Ḥajjāj b. Yūsuf based on the letters he wrote to him in his capacity as secretary (kātib) on behalf of the Umayyad governor of Khurasan. As such, Yahyā b. Ya'mar was a predecessor of al-Jāhiz and a contemporary of the famous kuttāb, 'Abd al-Hamīd (d. ca. 132/750) and Ibn al-Muqaffa' (d. ca. 139/756). ${ }^{49}$ Finally, the strong intercon-

46 This manner of rationalising language by using qiyās as opposed to mainly relying on transmitted data $\left(s a m \bar{a}^{c}\right)$ demarcates, in retrospect, the traditional Basra/Kufa dichotomy.

47 Cf. al-Bukhārī, book 78 (Adab); Muslim, book 38 (Ādāb) and book 40 (Alfāz min al-adab); Abū Dā'ūd, book 40 (Adab); al-Tirmidhī, book 40 (al-Isti'dhān wa-l-ādāb) and book 41 (Adab); al-Nasāì̄, book 49 (Ādāb al-quḍāt); Ibn Mājā, book 33 (Adab).

48 Jaakko Hämeen-Anttila, "Adab a) Arabic, early developments," in Encyclopaedia of Islam THREE, Yearbook, 2014 (Leiden: Brill, 2019), 26-35.

49 The kuttāb 'Abd al-Ḥamīd b. Yahyā and 'Abd Allāh b. al-Muqaffa' were important contributors to the development of Arabic literary prose in general and amongst the earliest epistolographers in Arabic; see Wadād al-Qāạīi, "Abd al-Ḥamīd b. Yahyyā al-Kātib," in Encyclopaedia of Islam THREE, Yearbook 2009 (Leiden: Brill, 2019), 14-17; Francesco Gabrieli, "Ibn al-Muḳaffac," in Encyclopaedia of Islam, 2nd ed. (Leiden: Brill, 1971), 3:883-885. 
nection between grammar and $a d a b$ - in the sense of the study of language and literature, as we know it from al-Mubarrad's (d. 285/898) introduction to his Kämil-is confirmed by this study. ${ }^{50}$

\section{Bibliography}

Abū Ḥāmid, Aḥmad b. Muḥammad b. Shaybān al-Tirmidhī. (Makhțūt farìd nafiss 'an) Marātib al-naḥwiyyīn. Edited by Hāshim al-Ṭa“ān. Al-Mawrid 3, no. 2 (1974): 137-144. Abū al-Ṭayyib, 'Abd al-Wahīd b. 'Alī. Marātib al-naḥwiyyīn. Edited by Muhammad Abū al-Faḍll Ibrāhīm. Cairo: Maktabat Nahḍa, 1955.

Åkesson, Joyce. "Șarf." In Encyclopaedia of Arabic Language and Linguistics, vol. 4. Edited by Kees Versteegh, Mushira Eid, Alaa Elgibali, Manfred Woidich and Andrzej Zaborski, 118-122. Leiden: Brill, 2008.

Bernards, Monique. "Awā’il." In Encyclopaedia of Islam THREE. Yearbook 2014. Edited by Kate Fleet, Gudrun Krämer, Denis Matringe, John Nawas and Everett Rowson, 120-127. Leiden: Brill, 2019.

Bernards, Monique. “Abū l-Aswad al-Du’alī." In Encyclopaedia of Islam THREE. Yearbook 2012. Edited by Kate Fleet, Gudrun Krämer, Denis Matringe, John Nawas and Everett Rowson, 62-64. Leiden: Brill, 2019.

Bernards, Monique. "Pioneers of Arabic Linguistic Studies." In In the Shadow of Arabic: The Centrality of Language to Arabic Culture. Studies Presented to Ramzi Baalbaki on the Occasion of his Sixtieth Birthday, edited by Bilal Orfali, 197-22o. Leiden: Brill, 2011. Bernards, Monique. “Grammarians' Circles of Learning: A Social Network Analysis.” In 'Abbasid Studies II, edited by John Nawas, 143-164. Leuven: Peeters, 2010.

Bernards, Monique. "Medieval Muslim Scholarship and Social Network Analysis: A Study of the Basra/Kufa Dichotomy in Arabic Grammar." In Ideas, Images, and Methods of Portrayal: Insights into Classical Arabic Literature and Islam, edited by Sebastian Günter, 129-151. Leiden: Brill 2005.

Bernards, Monique, and John Nawas. "A Preliminary Report of the Netherlands Ulama Project (NUP): The Evolution of the Class of Ulama in Islam with Special Emphasis on the Non-Arab Converts (mawali) from the First through Fourth Century A.H." In

50 "This is a book we have composed in order to bring together various $\bar{a} d \bar{a} b$ : prose, good verse, famous proverbs, eloquent homilies, and a selection of celebrated speeches and stylish letters. Our intention is to explain every unusual expression appearing in this book as well as every concept that is not readily understandable, and to offer detailed comments on every syntactical problem that might occur, so that the book can stand by itself and will not oblige the reader to have recourse to anyone else for explanations" (translation from Susanne Enderwitz, "Adab b) and Islamic scholarship in the 'Abbāsid period," in Encyclopaedia of Islam THREE, Yearbook 2013 (Leiden: Brill, 2019), 73-77). 
Law, Christianity and Modernism in Islamic Society, edited by Urbain Vermeulen and Jan M.F. van Reeth, 97-107. Leuven: Peeters, 1998.

Bohas, Georges, Jean-Patrick Guillaume and Djamel Kouloughli. The Arabic Linguistic Tradition. London and New York: Routledge, 199 o.

Carter, Michael G. "Les origines de la grammaire Arabe." Revue des études islamiques 40 (1972): 69-97.

Carter, Michael G. Sībawayhi. Makers of Islamic Civilization. Oxford: I.B. Tauris, 2004.

Enderwitz, Susanne. "Adab b) and Islamic Scholarship in the 'Abbāsid Period." In Encyclopaedia of Islam THRE E. Yearbook 2013. Edited by Kate Fleet, Gudrun Krämer, Denis Matringe, John Nawas and Everett Rowson, 73-77. Leiden: Brill, 2019.

Erickson, B.H. "Social Networks and History: A Review Essay." Historical Methods 30 (1997): 149-157.

Fahd, Toufic. "Ibn Sirīn." In Encyclopaedia of Islam, 2nd edition, vol. 3. Edited by P. Bearman, Th. Bianquis, C.E. Bosworth, E. van Donzel, W.P. Heinrichs, 947-948. Leiden: Brill, 1971.

Fleisch, Henri. Préliminaires, phonétique, morphologie nominale, vol. 1, Traité de philologie Arabe. Beirut: Imprimerie Catholique, 1961.

Gabrieli, Francesco. "Ibn al-Mukaffa'. In Encyclopaedia of Islam, 2nd edition, vol. 3. Edited by P. Bearman, Th. Bianquis, C.E. Bosworth, E. van Donzel, W.P. Heinrichs, 883-885. Leiden: Brill, 1971.

Gilliot, Claude. “Abdallāh Ibn 'Abbās." In Encyclopaedia of Islam THREE. Yearbook 2012. Edited by Kate Fleet, Gudrun Krämer, Denis Matringe, John Nawas and Everett Rowson, 41-55. Leiden: Brill, 2019.

Hämeen-Anttila, Jaakko. “Adab a) Arabic, Early Developments." In Encyclopaedia of Islam THREE. Yearbook 2014. Edited by Kate Fleet, Gudrun Krämer, Denis Matringe, John Nawas and Everett Rowson, 26-35. Leiden: Brill, 2019.

Heinrichs, Wolfhart. "The Classification of the Sciences and the Consolidation of Philology in Classical Islam." In Centres of Learning: Learning and Location in Pre-modern Europe and the Near East, edited by Jan Willem Drijvers and Alasdair A. MacDonald, 119-139. Leiden: Brill, 1995.

Ibn Ḥajar, Shihāb al-Dīn Aḥmad b. 'Alī b. Ḥajar al-'Asqalānī. Kitāb Tahdhīb al-tahdhīb. 14 vols. Beirut: Dār al-Fikr, 1984.

Ibn Ḥibbān, Muḥammad b. Ḥibbān b. Aḥmad Abī Ḥātim. Kitāb al-Thiqāt. 7 vols. Hyderabad, 1973.

al-Jazarī, Shams al-Dīn Abū al-Khayr Muḥammad b. Muḥammad. Ghāyat al-nihāya fì țabaqāt al-qurrā'. Edited by Gotthelf Bergsträsser. 2 vols. Cairo: Maktabat al-Khānjī, 1932-1935.

Juynboll, Gautier H.A. “Abū Hurayra." In Encyclopaedia of Islam THRE E. Yearbook 2007. Edited by Marc Gaborieau, Gudrun Krämer, Denis Matringe, John Nawas and Everett Rowson, 133-136. Leiden: Brill, 2019. 
al-Mizzī, Jamāl al-Dīn Abū al-Hajjāj Yūsuf. Tahdhīb al-kamāl fì asmā̄ al-rijāl. Edited by Bashshār 'Awwād Ma'rūf. 35 vols. Beirut: Mu’assasat al-Risāla, 1993.

Pellat, Charles. "Katāda b. Di'āma." In Encyclopaedia of Islam, 2nd edition, vol. 4. Edited by P. Bearman, Th. Bianquis, C.E. Bosworth, E. van Donzel, W.P. Heinrichs, 748. Leiden: Brill, 1978.

Pellat, Charles. Le milieu bașrien et la formation de Ğăhiz. Paris: Adrien-Maisonneuve, 1953 .

Papoutsakis, Nefeli. "al-Farazdaq." In Encyclopaedia of Islam THREE. Yearbook 2012. Edited by Kate Fleet, Gudrun Krämer, Denis Matringe, John Nawas and Everett Rowson, 467-471.

al-Qāḍī, Wadād. “Abd al-Ḥamīd b. Yahyyā al-Kātib.” In Encyclopaedia of Islam THREE. Yearbook 2oog. Edited by Gudrun Krämer, Denis Matringe, John Nawas and Everett Rowson, 14-17. Leiden: Brill, 2019.

al-Qifțī, Jamāl al-Dīn Abū al-Ḥasan 'Alī b. Yūsuf. Inbāh al-ruwāt 'alā anbāh al-nuḥāt.

Edited by Muḥammad Abū al-Fạ̣l Ibrāhīm. 4 vols. Cairo: Dār al-Fikr and Beirut: Mu'assasat al-Kutub, 1986.

al-Ṣafadī, Șalāḥ al-Dīn Khalīl b. Aybak. Kitāb al-wāfí bi-l-wafayāt. Edited by various editors. 30 vols. Beirut/Wiesbaden: Franz Steiner Verlag, 1962-2010.

Scott, John. Social Network Analysis: A Handbook. 2nd edition. Beverley Hills and London, 2000.

Sezgin, Fuat, Geschichte der arabischen Schriftums: Band IX Grammatik bis ca. $430 \mathrm{H}$. Leiden: Brill, 1984.

al-Sīrāfî, Abū Sa'̄id al-Ḥasan b. 'Abd Allāh, Akhbār al-naḥwiyyīn al-Bașriyyīn. Edited by Fritz Krenkow. Paris: Paul Geuthner and Beirut: Imprimerie Catholique, 1936.

al-Suyūṭ̂̄, Jalāl al-Dīn 'Abd al-Raḥmān. Bughyat al-wu'āt fi țabaqāt al-lughawiyyīn wa-lnuḥāt. Edited by Muḥammad Abū al-Faḍl Ibrāhīm. 2 vols. Cairo: Dār al-Fikr, 1979 .

Talmon, Rafael. "Naḥwiyyūn in Sībawayhi's Kitāb." Zeitschift für Arabische Liguistik 8 (1982): 12-38.

Talmon, Rafael. "Who was the First Arab Grammarian? A New Approach to an Old Question." Zeitschift für Arabische Liguistik 15 (1985): 128-145.

Talmon, Rafael. "An Eighth-Century Grammatical School in Medina: The Collection and Evaluation of the Available Material." Bulletin of the School of Oriental and African Studies 48 (1985): 224-236.

al-Tanūkhī, Abū al-Mahạ̄in al-Mufaḍḍal b. Muhammad al-Ma'arrī. Ta’rīkh al-'ulamā' al-naḥwiyyīn min al-Bașriyyīn wa-l-Küfiyyīn wa-ghayrihim. Edited by 'Abd al-Fattāh Muhammad al-Ḥulw. Riyad: Dār al-Hilāl, 1981.

Versteegh, Kees. Greek Elements in Arabic Linguistic Thinking. Leiden: Brill, 1977.

Versteegh, Kees. Arabic Grammar and Qur'ānic Exegesis in Early Islam. Leiden: Brill, 1993.

Wasserman, Stanley, and Katherine Faust. Social Network Analysis: Methods and Applic- 
ations. Structural Analysis in the Social Sciences 8. Cambridge: Cambridge University Press, 1997.

al-Zubaydī, Abū Bakr Muḥammad b. al-Ḥasan. Ṭabaqāt al-naḥwiyyìn wa-l-lughawiyyīn. Edited by Muhammad Abū al-Fạ̣l Ibrāhīm. Cairo: Dār al-Maārifi, 1973. 